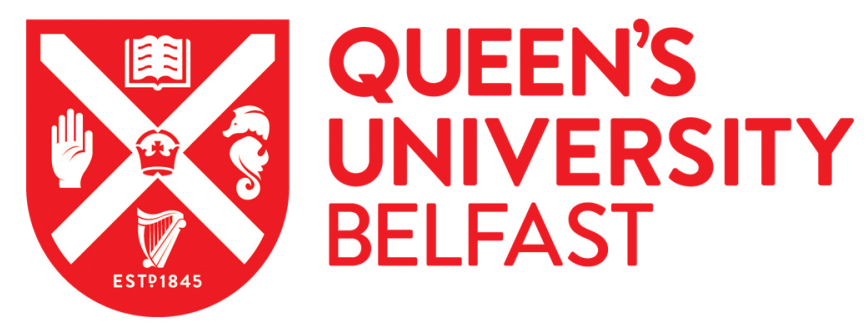

\title{
Complex responses of phototrophic communities to climate warming during the Holocene of northeastern Ontario, Canada
}

Elmslie, B. G., Gushulak, C. A. C., Boreux, M. P., Lamoureux, S. F., Leavitt, P. R., \& Cumming, B. F. (2019).

Complex responses of phototrophic communities to climate warming during the Holocene of northeastern

Ontario, Canada. Holocene. https://doi.org/10.1177/0959683619883014

\section{Published in:}

Holocene

\section{Document Version:}

Peer reviewed version

Queen's University Belfast - Research Portal:

Link to publication record in Queen's University Belfast Research Portal

\section{Publisher rights}

Copyright 2019 the Author(s).

This work is made available online in accordance with the publisher's policies. Please refer to any applicable terms of use of the publisher.

\section{General rights}

Copyright for the publications made accessible via the Queen's University Belfast Research Portal is retained by the author(s) and / or other copyright owners and it is a condition of accessing these publications that users recognise and abide by the legal requirements associated with these rights.

Take down policy

The Research Portal is Queen's institutional repository that provides access to Queen's research output. Every effort has been made to ensure that content in the Research Portal does not infringe any person's rights, or applicable UK laws. If you discover content in the Research Portal that you believe breaches copyright or violates any law, please contact openaccess@qub.ac.uk. 
Complex responses of phototrophic communities to climate warming during the Holocene of northeastern Ontario, Canada

3

4

5

6

7

8

9 Brett G. Elmslie ${ }^{1}$, Cale A.C. Gushulak ${ }^{1}$, Maxime P. Boreux ${ }^{1,2}$, Scott F. Lamoureux ${ }^{2}$, Peter R.

10 Leavitt $^{3,4}$, Brian F. Cumming ${ }^{1}$

12

13

14

15

16

17

18

19

20 Corresponding author: C.A.C. Gushulak

21

Email address: 16cacg@queensu.ca 


\section{Abstract}

32 Although the Holocene climate of North America has been generally well-studied, high regional

33 variability can obscure understanding of mechanisms underlying large-scale and long-term

34 variability. To address such a shortcoming, historical changes in Holocene climate in

35 northeastern Ontario were quantified using analysis of sedimentary pollen, diatoms, and

36 pigments in a small boreal lake. Modern Analog Technique (MAT) based on pollen was used to

37 reconstruct average temperature over the Holocene record of Charland Lake and showed average

38 temperature was $\sim 2{ }^{\circ} \mathrm{C}$ warmer than present conditions $\sim 7800-4500$ cal yr BP, a time period

39 which we define as the Holocene Thermal Maximum (HTM). Further investigation of pollen

40 data suggests a two-phase HTM: warm and dry conditions followed by warm and wet conditions

41 based on the occurrence of $P$. strobus and Cupressaceae (Thuja) pollen. Concomitant changes in

42 landscape features affected the sedimentological and phycological nature of the lake, as diatom

43 assemblages reflect delayed stabilization of the landscape following the draining of Glacial Lake

44 Ojibway $\sim 8200$ cal yr BP. In contrast, during a Post-HTM period, which was warmer than today

45 but cooler than the HTM, diatom and pigment data appear to be more influenced by indirect

46 effects of climate, such as lake-water thermal stratification and changes in plankton seasonality.

47 This study suggests that while climate greatly influenced regional forest ecology, landscape,

48 hydrological, and indirect climate effects were more influential on the phytoplankton

49 communities during the Holocene in northeast Ontario. These findings may provide insight into

50 how freshwater environments will respond to future anthropogenic warming in the region.

52 Keywords: Thuja, pollen, thermal stratification, landscape dynamics, diatoms, sedimentary 53 pigments 
The Holocene Thermal Maximum (HTM) was a period of enhanced warmth that

58 occurred during the early and middle Holocene (Viau et al., 2006; Renssen et al., 2009, 2012).

59 This warming has been well recorded and well-studied in the mid-to-high latitudes of the

60 Northern Hemisphere that experienced major climatic alterations following the last glacial

61 maximum (LGM) and deglaciation (Whitlock and Bartlein, 1997; Carlson et al., 2008). The

62 cause of the HTM has largely been attributed to an increase in solar insolation, due to orbital

63 variation, which maximized at $\sim 10 \mathrm{ka} \mathrm{BP} \mathrm{(thousand} \mathrm{years} \mathrm{before} \mathrm{present)} \mathrm{(Ritchie} \mathrm{et} \mathrm{al.,} \mathrm{1983;}$

64 Bond et al., 2001). Despite the overall maximum solar insolation occurring at this time, the

65 specific regions of North America may not have experienced maximum warmth at the same time

66 or to the same degree (Renssen et al., 2009, 2012). In general, regions at higher latitudes

67 experienced greater amounts of warming than those at lower latitudes (Renssen et al. 2009, 2012;

68 Briner et al., 2016) and the western portion of the continent warmed earlier than the east, likely

69 due to downwind cooling effects of the melting Laurentide Ice Sheet (LIS) (Carlson et al., 2008;

70 Viau and Gajewski, 2009). Alongside the variation in onset, duration, and magnitude of warmth

71 experienced during the HTM in North America, reconstructions of Holocene precipitation levels

72 suggest a climatic dipole in which the west of the continent was dry while the east was wet

73 during the HTM (Shuman and Marsicek, 2016). To date, however, these studies have focused on

74 the continental United States and the Arctic or subarctic regions (Viau and Gajewski, 2009;

75 Briner et al., 2016; Shuman and Marsicek, 2016) and relatively little is known regarding the

76 nature of the HTM in the boreal region of east-central Canada (e.g., northern Ontario).

77 The boreal forest of northern Ontario spans $\sim 1500 \mathrm{~km}$, is one of the largest continuous

78 forests globally, and contains abundant fresh water in its wetlands, rivers, and innumerable small

79 lakes. Despite its size, the region is susceptible to anthropogenically-forced climate change 
80 (Price et al., 2013). Therefore, a characterization of landscape responses to analogs of past

81 climates may be useful for predicting effects of atmospheric warming and changes in regional

82 hydrology (Klemm et al., 2016; Navarro et al., 2018; Teller et al., 2018). Atmosphere-ocean-

83 vegetation models have suggested that the HTM in northern Ontario was $\sim 2-3{ }^{\circ} \mathrm{C}$ warmer than

84 the modern climate (Renssen et al., 2009, 2012). Recent work from northwest Ontario $(\sim 1200$

$85 \mathrm{~km}$ to the west of our study site) reveals that the HTM occurred from $\sim 8500-4500$ cal yr BP

86 (calendar years before present) and was $\sim 2{ }^{\circ} \mathrm{C}$ warmer than present conditions. This estimate was

87 calculated using a modern analog technique (MAT) calibration based on fossil pollen and a

88 regional set of modern pollen and climate data (Moos and Cumming, 2011). Associated dryer

89 conditions resulted in lower lake levels, increased algal production, an eastward shift of the

90 prairie-forest ecotone, and an increase in fire activity (Moos et al., 2009; Moos and Cumming,

91 2011, 2012; Karmakar et al., 2015a, 2015b). Despite this research, there has been little work

92 examining the HTM of northeastern Ontario, Canada, which is a problem this paper seeks to

93 address.

94 Only one Holocene-scale palynological study has documented Holocene climate

95 variability in northeast Ontario (Liu, 1990). This study examined three sediment cores in a north-

96 south transect of eastern Ontario. One of these sites, Lake Six, is $6 \mathrm{~km}$ away from our study site

97 so comparisons to Liu (1990) refer to the Lake Six record. In Liu (1990), the author showed a

98 delayed, but protracted HTM period occurring from 7-2.5 ka BP at Lake Six. This was defined

99 by increases in Pinus strobus, a typical taxon of the warm Great Lakes-St. Lawrence forest, and

100 in Cupressaceae. Liu (1990) interpreted the presence of Cupressaceae pollen as belonging to

101 Thuja based on its co-occurrence with Thuja macrofossils within the sediment core. These data

102 suggest that the HTM of northeast Ontario was wet, agreeing with studies at similar longitudes to 
103 the south (Viau et al., 2006; Shuman and Marsicek, 2016). A similar interpretation has been

104 made by Carcaillet et al. (2001) who used charcoal analysis to infer that low fire activity during

105 the this time in western Quebec was due to enhanced water availability. Unfortunately, Liu's

106 (1990) climatic results from Lake Six are supported by only three radiocarbon dates. With these

107 few data points there is likely considerable error regarding the temporal boundaries of HTM

108 warming and it is likely that the upper boundary $(\sim 2.5 \mathrm{ka} \mathrm{BP})$ is overestimated based on studies

109 from northwest Ontario (Moos and Cumming, 2011, 2012). Improved geochronology, as well as

110 replicate sites in the region, are important to better define the onset and duration of the HTM in

111 northeast Ontario, as well as its effects on lake ecosystems.

112 This paper attempts to quantify changes in climate systems in northeastern Ontario using

113 robust analysis of fossil pollen to reconstruct climatic and vegetation characteristics, as well as

114 fossil diatoms and pigments from aquatic phototrophs to quantify the effects of climate

115 variability on lake production and community composition. Diatoms are ideal for these

116 objectives, as certain species have well-documented optima for nutrients and other physical and

117 chemical limnological characteristics (water-depth, $\mathrm{pH}$, salinity, stratification regime, etc.). By

118 examining changes in diatom species which are known to be nutrient-controlled, changes in

119 nutrient levels can be inferred (Douglas and Smol, 1999; Lotter et al., 1999; Rühland and Smol,

120 2005; Cumming et al., 2015). Similarly, fossil pigments (chlorophylls, carotenoids, derivatives)

121 often preserve after the loss of morphological remains of non-siliceous phytoplankton and

122 phytobenthos, and are used to estimate historical changes in the abundance of primary producers,

123 as well as their gross community composition (Leavitt et al., 1994a, 1997; Hodgson et al., 1998;

124 Hall et al., 1999). Taken together, analysis of these proxies are can be used to answer three

125 questions related to the HTM: a) when and for how long did the HTM take place in northeast 
126 Ontario; b) what was the degree of warming that occurred during the HTM of this region and

127 was the warmer climate wet or dry, and; c) what was the response in algal production to this

128 warmer climate?

129

Methods

131

132

133

\section{Study area}

135 Ontario, Canada, immediately west of Kettle Lake Provincial Park and is located within $6 \mathrm{~km}$ of

136 Lake Six, site of the only other study of Holocene climate in northeast Ontario (Liu, 1990).

137 Charland Lake, like other basins in the region, formed when Glacial Lake Ojibway drained off

138 the landscape of northeastern Ontario $\sim 8200$ cal yr BP (Veillette, 1994; Carlson et al., 2008; Roy

139 et al., 2015; Margold et al., 2018). The lake is small ( 20 ha), $16 \mathrm{~m}$ deep, and $274 \mathrm{~m}$ above sea

140 level. The climate of the region is humid continental (Koppen Dfb) which is characterized by wet

141 summers and long, cold winters. Average temperature is $\sim 1.8^{\circ} \mathrm{C}$ (Environment Canada,

142 2019).Modern boreal forest in the area is composed mainly of white (Picea glauca) and black

143 spruce (Picea mariana) in lowlands with jack pine (Pinus banksiana) and white birch (Betula

144 papyrifera) on upland sites. Charland Lake occurs in the 'Great Clay Belt' of northern Ontario.

145 The bedrock is composed of metamorphosed Precambrian granites and granodiorites which are 146 overlain by Quaternary glacial landforms and extensive glaciolacustrine clay deposits laid down

147 by Glacial Lake Ojibway (Veillette, 1994; Roy et al, 2011, 2015). [insert Figure 1.]

149 Figure 1. (A) Bathymetric map of Charland Lake with $2 \mathrm{~m}$ contours. The black star represents 150 the location of the piston core that was taken from a depth of $\sim 16 \mathrm{~m}$. (B) A reference map of 
151 Ontario with the Charland Lake coring site indicated by a black star.

\section{Sample collection}

Bathymetric data points were collected from Charland Lake using a Garmin GPS-Map

155 Sounder 238 connected to a Toughbook computer with Bathymetric Automated Survey System

156 (B.A.S.S.) software, v 2.4 (Levec, 2001). These data points were converted to shape files and

157 used to produce the bathymetric map in ArcMap 10.5 (Esri, 2016). A $473 \mathrm{~cm}$ long sediment core

158 was collected from a depth of $\sim 16$ m on 19 June 2014 using a 1-m square-rod Livingstone piston

159 corer with an internal diameter of $5.1 \mathrm{~cm}$ (Wright, 1967; Wright et al. 1984; Glew et al., 2001).

160 Approximately $10 \mathrm{~cm}$ of material from the top of the core was lost during horizontal extrusion in

161 the field. To assure collection of an undisturbed sediment-water interface, and to be able to

162 accurately date the top of the piston core, a gravity core (internal diameter $7.62 \mathrm{~cm}$ ) was taken at

163 the same site using a modified gravity corer (Glew 1989) and was sectioned into $0.5 \mathrm{~cm}$

164 intervals in the field. The piston core exhibited distinct units, with organic gyttja $0-313 \mathrm{~cm}$, grey

165 clays from 313-337 cm, organic-rich material from $337-417 \mathrm{~cm}$, and basal clay deposition

166 below that level. In this paper, we refer to these clay layers in order of deposition, making the

167 clay deposit from $417-473 \mathrm{~cm}$ 'the first clay layer' and the deposit from $313-337 \mathrm{~cm}$ 'the second

168 clay layer'. The piston core was wrapped in 1-m sections on site and transported in a cooler to

169 the Paleoecological Environmental Assessment \& Research Laboratory (PEARL) at Queen's

170 University where they were stored horizontally in a cold room at $\sim 4^{\circ} \mathrm{C}$. Half of the core was

171 then sectioned into $1 \mathrm{~cm}$ intervals, while the other half was archived.

\section{Analyses}




\section{Chronology}

The top $13 \mathrm{~cm}$ of the gravity core were dated by using a constant rate of supply (CRS) model applied to ${ }^{210} \mathrm{~Pb}$ gamma activity of the sediments. This was done to assess the date of the top of the piston core as the sediment-water interface was lost during extrusion. The ${ }^{14} \mathrm{C}$ chronology for the piston core was determined by dating a concentrated sample of pollen grains from eight sediment samples with accelerator mass spectrometry (AMS). Pollen grains were isolated from lake sediments by LacCore using a procedure similar to Brown et al. (1989) and measured for ${ }^{14} \mathrm{C}$ at the Lawrence Livermore National Laboratory. An age-depth relationship based on these radioisotopic data was constructed using Bayesian age modeling with the BACON (v. 2.2) modeling package in $\mathrm{R}$ (R Core Team, 2015) with the IntCal13 ${ }^{14} \mathrm{C}$ calibration curve (Blaauw and Christen, 2011; Reimer et al., 2013). Default settings outlined by Goring et al. (2012) were used to determine the gamma distribution of the accumulation rate, which were in agreement with the posterior distribution of activities (Blaauw and Christen, 2011). The prior memory was set to a mean of 0.3 and shape of 25 to accommodate small shifts in accumulation rates. The sensitivity of prior memory parameters was tested and changes in mean and shape did not result in large changes to the model.

\begin{tabular}{|l|l|l|l|l|l|l|}
\hline & & & & & & \\
\hline & & & & & & \\
\hline & & & & & & \\
\hline & & & & & & \\
\hline & & & & & & \\
\hline & & & & & & \\
\hline & & & & & & \\
\hline & & & & & & \\
\hline
\end{tabular}




\begin{tabular}{|l|l|l|l|l|l|l|}
\hline & & & & & & \\
\hline & & & & & & \\
\hline
\end{tabular}

Dry mass and organic matter

196 Dry mass and percent organic matter was determined through standard loss-on-ignition

197 procedures (Heiri et al., 2001) on 60 intervals throughout the sediment core.

199 Pollen

$200 \quad$ Pollen samples were prepared at every $8 \mathrm{~cm}$ (60 samples total) using a modification of 201 the method of Bennett and Willis (2001). Sediment samples were spiked with two exotic

202 Lycopodium tablets (batch no. 1031) and digested with 10\% hydrochloric acid and 10\%

203 potassium hydroxide before being sieved through a $10 \mu \mathrm{m}$ mesh. The remaining sediment was

204 further digested in 40\% hydrofluoric acid and then acetolyzed, deflocculated with 10\% sodium 205 metaphosphate, stained with Safranin, and mounted on microscope slides in silicon oil. Pollen 206 grains were counted with a Leica light microscope with a 40x differential-interference-contrast 207 objective. A minimum of 400 pollen grains were counted per sample except those in which 208 pollen concentration was low and multiple coverslips needed to be counted. In those cases, a

209 minimum of 300 grains were counted. Pollen grains were identified to the lowest possible

210 taxonomic resolution based on published references (Bassett et al., 1978; McAndrews et al., 211 1978; Kapp et al., 2000).

212

213 Pigments

214 Subsamples of wet sediment were used for determination of photosynthetic pigment 
215 concentrations from 59 intervals throughout the core at the University of Regina's Institute of

216 Environmental Change and Society (IECS). Sedimentary pigment analysis was undertaken

217 following procedures outlined in Leavitt and Hodgson (2001). Pigment concentrations are

218 reported as nmoles pigment $\mathrm{g}^{-1}$ gram organic matter, a unit which is linearly proportional to the

219 standing stock of phytoplankton in decadal-scale monitoring programs (Leavitt et al., 1994a). An

220 Agilent model 1100 high-performance liquid chromatography (HPLC) system with photodiode

221 array detector was calibrated using commercial pigment standards from DHI (Denmark).

222 Analysis included the main $a$ - and $b$-phorbins (chlorophyll, pheophytin), as well as chemically-

223 stable, taxonomically-diagnostic pigments representing total algal abundance ( $\beta$-carotene),

224 cryptophytes (alloxanthin), total cyanobacterial (echinenone), colonial cyanobacteria

225 (myxoxanthophyll), Nostocales cyanobacteria (canthaxanthin), chlorophytes (Chl b),

226 chlorophytes + cyanobacteria (lutein-zeaxanthin), siliceous algae (fucoxanthin), mainly diatoms

227 (diatoxanthin), and anaerobic purple sulfur bacteria (okenone) following Leavitt and Hodgson,

228 (2001). Historical changes in the lacustrine preservation environment were recorded as changes

229 in the ratio of labile precursor ( $\mathrm{Chl} a$ ) to stable products (pheophytin $a$ ), both ubiquitous

230 pigments used to estimate total phototrophic abundance (Leavitt and Hodgson, 2001).

232 Diatoms

233 Diatom samples were prepared using $\sim 0.2-0.3 \mathrm{~g}$ of wet sediment, taken every $8.0 \mathrm{~cm}$, for 234 a total of 59 subsamples. Samples were digested in a 1:1 molar solution of concentrated nitric

235 and sulphuric acids before being brought to a slightly acidic $\mathrm{pH}$ through repeated rinses with

236 double-deionized water. Diatom slurries were reduced to a volume of $\sim 5 \mathrm{ml}$ by aspiration

237 following sedimentation, and spiked with a solution of microspheres of known concentration 
238 equivalent to $4 \mathrm{ml}$ of a $2.0 \times 10^{7}$ spheres $/ \mathrm{ml}$ solution for organic samples and $0.2 \mathrm{ml}$ of a $2.0 \times$

$23910^{7}$ for clay-rich samples. Samples were plated on coverslips in a series of four dilutions and then

240 mounted to slides using Naphrax ${ }^{\circledR}$. Diatoms valves were identified and enumerated using a Leica

241 DMRB microscope under a $100 \times$ Fluotar objective $($ NA of objective $=1.3)$ and differential

242 interference contrast optics at $1000 \times$ magnification. For most diatom samples a minimum of 400

243 valves were counted, or, if the concentration of valves was exceptionally low, until five transects

244 were completed. Diatoms were identified to species or lower taxonomic units using the standard

245 references (Krammer and Lange-Bertalot, 1986, 1988, 1991a, 1991b; Cumming et al., 1995).

246 Chryosphyte scales were enumerated alongside diatoms, but were not taxonomically identified.

248 Numerical analyses

249 Fossil pollen, pigment, and diatom data were plotted using the computer program Tilia 250 v.2.0.2 (Grimm, 2004). Pollen taxa present at greater than $2 \%$ abundance in at least two samples 251 and diatom species with greater than 5\% abundance in at least three samples were included in the 252 plots. Pollen concentration was calculated with the formula: (exotic Lycopodium spores added $\mathrm{x}$ 253 fossil pollen counted) / exotic Lycopodium spores counted (Bennett and Willis, 2001) and 254 standardized to dry mass. A depth-constrained cluster analysis (CONISS) (Grimm, 1987) was 255 performed on the pollen assemblage to identify major differences in the pollen assemblage. The 256 statistical significance of zones delineated by CONISS were validated with a broken-stick model 257 by rioja package in R (Juggins, 2015; R Core Team, 2015).

258 Modern Analog Technique (MAT) was used to quantitatively reconstruct mean annual 259 temperature over the Holocene record of Charland Lake using the $\mathrm{C} 2$ software program (Juggins, 260 2003). Modern pollen taxa and climate data were collected from the North American pollen 
261 database (Whitmore et al., 2005; Williams et al., 2006) to form a regional calibration set. A total

262 of 305 samples between $45-60^{\circ} \mathrm{N}$ and $75-90^{\circ} \mathrm{W}$ were selected to form the calibration set which

263 captured the transition between the boreal and mixed-wood forests to the south of Charland

264 Lake. The fossil pollen from Charland Lake are well represented in the modern pollen dataset so

265 it is likely that this group of sites should provide strong analogs for the assemblages found in the

266 Charland Lake sediment core over the Holocene. Cupressaceae pollen was removed from the

267 reconstruction model as this pollen type can represent both Juniperus and Thuja which have very

268 different climatic preferences (Yu, 1997). Annual average temperature was reconstructed using

269 the five closest analogs compared to fossil pollen interval with squared-chord measurement of

270 similarity (Overpeck et al., 1985; Viau et al., 2006; Viau and Gawjewski, 2009) and bootstrap

271 cross-validation (bootstrapped $\mathrm{r}^{2}=0.95$, root-mean-square-error-of-prediction $($ RMSEP) $=0.88$ ).

272 The 305 site calibration set was tested against itself using the same method described above to

273 discern the distribution of dissimilarities among the analogs used for the temperature

274 reconstructions. Each of the five closest analogs used for each fossil interval was within the $20^{\text {th }}$

275 percentile of the 305 sites. The majority were within the $10^{\text {th }}$ percentile. This resulted in average

276 dissimilarity values to be less than $30 \%$ which corresponds to the top $10^{\text {th }}$ percentile for each

277 reconstructed site.

278 Pigments were restricted to common sedimentary compounds of known chemical

279 stability (see above). Analysis of similarities (ANOSIM) using a Bray-Curtis similarity

280 coefficient and 999 permutations, were used to test the null hypothesis that there was no

281 difference in diatom and pigment composition between the pollen-inferred climate zones (Clarke

282 and Warwick, 1994). Analyses were performed using both non-transformed and square-root

283 transformed species data. ANOSIM tests were performed on diatom relative abundance and 
284 concentration and pigment concentration data. ANOSIM tests were calculated using the PAST 3

285 software package (Hammer et al., 2001; Hammer and Harper, 2006). The sample from a depth of

$286440 \mathrm{~cm}$ was determined to be an outlier and was removed prior to any statistical analyses.

287 Following the ANOSIM analysis, SIMPER tests (also performed in PAST), were used to

288 calculate the contribution of each species to the average dissimilarity between the two groups.

289 Post-hoc t-tests assuming unequal variance were performed to identify the significant difference

290 between the pollen-inferred climate zones for individual sedimentary pigments using Microsoft

291 Excel. The index of chrysophyte scales to diatom frustules (scale-to-diatom index) was

292 calculated using the formula: scales/ (diatoms + scales) $\times 100$ (Moos et al., 2005).

\section{Results}

\section{Age model}

The activity of ${ }^{210} \mathrm{~Pb}$ in the Charland Lake gravity core was adequate to produce an age-

299 depth model for the top $12 \mathrm{~cm}$ of sedimentation (Supplemental Figure 1). Background levels of

$300{ }^{210} \mathrm{~Pb}$ were reached below that depth. Approximately $10 \mathrm{~cm}$ were lost from the first section of the

301 piston core during extrusion. Based on our CRS model, this would mean the top of the piston

302 core would correspond to an age of 0 cal yr BP with $\mathrm{BP}=1950$.

304 1). Bayesian modeling of the depth- ${ }^{14} \mathrm{C}$ age relationship revealed a relatively constant rate of

305 deposition over the period of study (Figure 2). Overall, the errors of the inferred ages for

306 intervals in the sediment core were relatively low ( $\pm 30-40$ years). The calibrated ${ }^{14} \mathrm{C}$ dates

307 increased in age with increasing depth and follows an approximately linear trend with

308 cumulative core depth. [insert Figure 2.] 
Table 1. Summary of the ${ }^{14} \mathrm{C}$-dating results on pollen isolated from selected intervals from the sediment cores from Charland Lake. All analyses were performed based on pollen isolated at the LacCore Facility at the University of Minnesota, and dated at Lawrence Livermore National Laboratory. The mean age of the distribution is presented in "Cal yr BP". The top date was generated through ${ }^{210} \mathrm{~Pb}$ dating and a CRS model.

\begin{tabular}{|c|c|c|c|c|c|c|}
\hline Core & $\begin{array}{c}\text { Cumulative } \\
\text { depth in } \\
\text { piston core } \\
(\mathrm{cm})\end{array}$ & $\delta^{13} \mathrm{C}$ & $\begin{array}{c}{ }^{14} \mathrm{C} \text { Age } \pm \\
\mathrm{SD}\end{array}$ & Cal yr BP & $\begin{array}{c}2-\sigma \text { cal yr } \\
\text { BP range } \\
(\text { min-max })\end{array}$ & CAMS \# \\
\hline $\mathrm{C} 2 \mathrm{~S} 1$ & 0 & $\mathrm{~N} / \mathrm{A}$ & $\mathrm{N} / \mathrm{A}$ & 0 & $-6-28$ & N/A \\
\hline $\mathrm{C} 2 \mathrm{~S} 1$ & 45.5 & -28 & $1170 \pm 30$ & 1081 & $976-1187$ & 171192 \\
\hline $\mathrm{C} 2 \mathrm{~S} 2$ & 143.5 & -28 & $2505 \pm 40$ & 2623 & $2451-2749$ & 171205 \\
\hline $\mathrm{C} 2 \mathrm{~S} 2$ & 178.5 & -28 & $3035 \pm 30$ & 3260 & $3133-3360$ & 171201 \\
\hline $\mathrm{C} 2 \mathrm{~S} 3$ & $204-206$ & -28 & $3480 \pm 30$ & 3762 & $3649-3863$ & 176019 \\
\hline $\mathrm{C} 2 \mathrm{~S} 3$ & 262.5 & -28 & $4400 \pm 30$ & 4925 & $4846-5037$ & 171194 \\
\hline $\mathrm{C} 2 \mathrm{~S} 4$ & $305-306$ & -28 & $4560 \pm 35$ & 5390 & $5238-5570$ & 176020 \\
\hline $\mathrm{C} 2 \mathrm{~S} 4$ & 401.5 & -28 & $6235 \pm 30$ & 7159 & $6999-7272$ & 171206 \\
\hline $\mathrm{C} 2 \mathrm{~S} 5$ & 437.5 & -28 & $6995 \pm 40$ & 7815 & $7670-7947$ & 171202 \\
\hline
\end{tabular}

Figure 2. Age-depth model run for the Charland Lake core using BACON (Version 2.2). Top left panel: Markov Chain Monte Carlo model iterations. Top middle panel: Prior (heavy line) and posterior (solid) distribution of accumulation rate. Top right panel: Prior (heavy line) and posterior (solid) distribution of model memory. Bottom panel: calibrated ${ }^{14} \mathrm{C}$ dates and the agedepth model. The outer dotted lines indicate $95 \%$ confidence intervals. The central dotted line is the 'best' model based on the weighted mean age.

\section{Pollen}

Four statistically-significant pollen zones were identified in the Charland Lake core 
327 through CONISS and validated with the broken stick model (Figure 3; Supplemental Figure 2).

328 CONISS analysis demonstrated that breaks between zones occur at cumulative depths of 85, 253,

329 and $445 \mathrm{~cm}$. Reconstructed average temperature showed major changes in line with these

330 boundaries and we labelled the zones as the Pre-HTM, HTM, Post-HTM, and Modern climate

331 zones (Figure 3). Standard error for the temperature reconstructions were generally low and on

332 average did not exceed $0.5^{\circ} \mathrm{C}$ above or below the estimate (Figure 4). Error is larger in the Pre-

333 HTM zone, but even considering the upward limit of the error there is still a large and noticeable

334 increase in temperature when entering the HTM zone (Figure 4).

335 The Pre-HTM zone occurred from 473-445 cm ( 8200-7800 cal yr BP) and showed

336 mixed dominance of Picea and Pinus; P. bankisana and P. resinosa could not be distinguished.

337 This zone also included a relatively low abundance of arboreal pollen compared to rest of the

338 core, as well as more abundant spores and pollen from Sphagnum, fern, and Cyperaceae.

339 Reconstructed average temperature was approximately $-0.5-0{ }^{\circ} \mathrm{C}$ in this zone. The HTM zone

340 occurred from 445-253 cm ( 7800-4500 cal yr BP) and showed a major increase in

341 reconstructed temperature (Figure 3, Figure 4). Average temperatures of $\sim 2-3{ }^{\circ} \mathrm{C}$ were consistent

342 across this zone, but there appears to be two distinct floral assemblages within the warm period.

343 The first was marked by an increase in the P. banksiana/resinosa and the second with an

344 increase in Pinus strobus and Cupressaceae. Organic sedimentation also began in this zone,

345 concomitant with pollen concentration rapidly increasing before falling substantially at the onset

346 of the second clay layer. The Post-HTM period (253-85 cm, 4500-1700 cal yr BP) showed an

347 increase in Picea, P. banksiana/resinosa, and Betula pollen, as those of P. strobus and

348 Cupressaceae declined. This is reflected in the MAT reconstruction as average temperature fell

349 by $\sim 1^{\circ} \mathrm{C}$. Pollen concentration was variable in this zone but generally increased during the 
350 earlier portion before declining after $\sim 3300 \mathrm{cal}$ yr BP. The Modern Zone $(85-0 \mathrm{~cm}, \sim 1700-0 \mathrm{cal}$

351 yr BP) showed a general decrease in pollen concentration and further decreases of $P$. strobus.

352 Picea became predominant in this zone with P. banksiana/resinosa and Betula experiencing

353 minor decreases compared to the Post-HTM zone. Reconstructed average temperature slowly

354 declined by $\sim 0.5^{\circ} \mathrm{C}$ throughout this zone. The concentration of pollen types was also plotted and

355 can be found in the supplemental materials (Supplemental Figure 3).

$356 \quad$ [insert Figure 3]

357 Figure 3. Relative abundance of abundant ( $>2 \%$ found in 2 sections of the core) pollen taxa in

358 Charland Lake. Total pollen concentration is also shown. Darker zones in Sediment Type

359 represent organic sedimentation in the piston core. Layered zones represent clay deposits.

360 Climate Zones are derived through CONISS. Reconstructed average temperature was estimated

361 through Modern Analog Technique calibration (bootstrapped $\mathrm{r}^{2}=0.95, \mathrm{RMSEP}=0.88$ ).

362 [insert Figure 4]

363 Figure 4. Reconstructed average temperature with error bars and percent dissimilarity of the

364 analogs used in the MAT temperature reconstruction of the Charland Lake record. Percent

365 dissimilarity refers to the mean dissimilarity of the five closest analogs used to reconstruct

366 annual temperature for each fossil interval. Zones are the CONISS-derived climate zones from

$367 \quad$ Figure 3.

\section{Pigments}

373 climate change and variation in pigment assemblages (Figure 5). Overall, preservation of 
374 pigments was poor in the Pre-HTM zone, with fossil concentrations below detection limit in

375 most samples. A similar absence of fossil pigments in the second clay layer suggests that the

376 near absence of sedimentary organic matter favored complete decomposition of carotenoids and

377 chlorophylls, irrespective of their inherent chemical lability, similar to patterns seen in glacially-

378 fed alpine lakes (Bunting et al., 2010). In contrast, concentrations of ubiquitous pigments ( $\beta$ -

379 carotene, Chl $a$, pheophytin $a$ ), and those from cryptophytes (alloxanthin), diatoms

380 (diatoxanthin), total cyanobacteria (echinenone), Nostocales cyanobacteria (canthaxanthin),

381 chlorophytes (pheophytin $b$ ) and chlorophytes+cyanobacteria (lutein-zeaxanthin) all increased

382 markedly at the base of the HTM zone, whereas more labile compounds (fuxoxanthin, Chl $b$ ) did

383 not. These patterns reflect the increase in okenone from obligate anaerobic purple sulfur bacteria,

384 an indicator of anoxia in deep-waters or sediment. Transition from the HTM to Post-HTM zone

385 was marked by significant increases in the concentration of most fossil pigments (Table 2, Figure

386 6). The Post-HTM zone was characterized by elevated concentrations of most pigments, often to

387 a historical maximum relative to other zones (e.g., $\beta$-carotene, lutein-zeaxanthin, okenone, and

388 canthaxanthin). In the Modern zone ( $0-85 \mathrm{~cm} ; \sim 1700-0$ cal yr BP), pigment assemblages were

389 marked by the first appearance of myxoxanthophyll from colonial cyanobacteria, increases in

390 concentrations of compounds from Nostocales cyanobacteria (canthaxanthin) and secondarily

391 total cyanobacteria (echinenone), and historical maxima of less chemically-stable pigments from

392 diatoms (fucoxanthin, diatoxanthin) and chlorophytes (Chl b). In contrast, fossil levels of

393 ubiquitous $\beta$-carotene and the mixed chlorophyte-cyanobacterial indicator, lutein-zeaxanthin,

394 declined slightly in the most recent zone. Relative to individual pigments, the ratio of labile

395 chlorophyll $a$ to stable phaeophytin $a$ (indicating the preservation environment) remained 
396 relatively constant through the core, with some variance within and between the clay bands of

397 the Pre-HTM and HTM zones (Figure 5). [insert Figure 5.]

399 Figure 5. Concentration of photosynthetic pigments (nmoles per gram organic matter) in

400 Charland Lake sediment core over time (cal yr BP). The ratio of chlorophyll $a$ to phaeophytin $a$,

401 an indicator of preservation, and organic matter (\%) are also shown. Darker zones in Sediment

402 Type represent organic sedimentation in the piston core. Layered zones represent clay deposits.

403 The dotted lines indicate the pollen-derived climate zones from Figure 3.

Table 2. Summary table of the results from a series of two sample post hoc t-tests assuming unequal variance conducted to identify significant differences in pigment concentrations between the HTM, Post-HTM, and Modern zones for sedimentary pigments. Bold cells indicate 408 significance.

409

\begin{tabular}{|c|c|c|c|c|c|}
\hline Zones & Canthaxanthin & Echinenone & Okenone & Alloxanthin & $\beta$-carotene \\
\hline $\begin{array}{l}\text { HTM, } \\
\text { Modern }\end{array}$ & $\begin{array}{l}t(22)-8.7=p= \\
<0.01\end{array}$ & $\begin{array}{l}t(12)-2.5=p= \\
0.03\end{array}$ & $\begin{array}{l}t(21)=-6.3= \\
p=<0.01\end{array}$ & $\begin{array}{l}t(26)-5.1=p= \\
<0.01\end{array}$ & $\begin{array}{l}t(21)=-1.9 p \\
=0.07\end{array}$ \\
\hline $\begin{array}{l}\text { HTM, Post- } \\
\text { HTM }\end{array}$ & $\begin{array}{l}t(44)-5.0=p= \\
<0.01\end{array}$ & $\begin{array}{l}t(43)=-4.5 p= \\
<0.01\end{array}$ & $\begin{array}{l}t(42)=-4.2= \\
p=<0.01\end{array}$ & $\begin{array}{l}t(31)-4.2=p= \\
<0.01\end{array}$ & $\begin{array}{l}t(43)=-4.1 p \\
=<0.01\end{array}$ \\
\hline \multirow[t]{2}{*}{$\begin{array}{l}\text { Post-HTM, } \\
\text { HTM }\end{array}$} & $\begin{array}{l}t(23)-4.2=p= \\
<0.01\end{array}$ & $\begin{array}{l}t(11)=-0.8 p= \\
0.44\end{array}$ & $\begin{array}{l}t(25)=-2.2= \\
p=0.04\end{array}$ & $\begin{array}{l}t(32)-1.4=p= \\
1.69\end{array}$ & $\begin{array}{l}t(24)=1.7 p= \\
0.1\end{array}$ \\
\hline & $\begin{array}{l}\text { Lutein- } \\
\text { zeaxathin }\end{array}$ & Myxoxanthopyll & Fucoxanthin & Chlorophyll $b$ & Diatoxanthin \\
\hline $\begin{array}{l}\text { HTM, } \\
\text { Modern }\end{array}$ & $\begin{array}{l}t(32)-2.5=p= \\
0.02\end{array}$ & $\begin{array}{l}t(10)-3.3=p= \\
<0.01\end{array}$ & $\begin{array}{l}t(16)-19.4=p \\
=<0.01\end{array}$ & $\begin{array}{l}t(10)-8.4=p= \\
<0.01\end{array}$ & $\begin{array}{l}t(25)-10.7= \\
p=<0.01\end{array}$ \\
\hline $\begin{array}{l}\text { HTM, Post- } \\
\text { HTM }\end{array}$ & $\begin{array}{l}t(36)-4.4=p= \\
<0.01\end{array}$ & N/A & $\begin{array}{l}t(25)-6.3=p \\
=<0.01\end{array}$ & $\begin{array}{l}t(22)-3.1=p= \\
<0.01\end{array}$ & $\begin{array}{l}t(41)-6.4=p \\
=<0.01\end{array}$ \\
\hline $\begin{array}{l}\text { Post-HTM, } \\
\text { Modern }\end{array}$ & $\begin{array}{l}t(25) 2.3=p= \\
0.03\end{array}$ & $\begin{array}{l}t(10)-3.3=p= \\
<0.01\end{array}$ & $\begin{array}{l}t(31)-4.6=p \\
=<0.01\end{array}$ & $\begin{array}{l}t(26) 0.3=p= \\
0.77\end{array}$ & $\begin{array}{l}t(19)-6.0=p \\
=<0.01\end{array}$ \\
\hline
\end{tabular}

412 pigment concentration among the three most recent zones. Specifically, the null hypothesis of no

413 difference between pigment concentrations among zones was rejected in comparisons of the 
414 HTM and Post-HTM zones, and between the Post-HTM and Modern zones (Table 3). A

415 SIMPER test identified lutein-zeaxanthin as the predominant pigment contributing to $40 \%$ of

416 the difference in composition between the HTM and Post-HTM zones (Table 4), and $29 \%$ of

417 the difference in composition seen between Post-HTM and Modern zones (Table 4). [insert

418 Figure 6].

420 Figure 6. Boxplots of pigment concentrations (nmol/g OM) within the a priori defined pollen-

421 derived climate zones (HTM $(n=24)$, Post-HTM $(n=21)$, Modern $(n=11))$. ANOVA tests were

422 run to test for significant differences between zones for $A) \beta$-carotene $(F(2,53)=8.2$, $p$-value $<$

423 0.01) B) lutein-zeaxanthin $(\mathrm{F}(2,53)=7.6$, p-value $<0.01) \mathrm{C})$ alloxanthin $(\mathrm{F}(2,53)=11.4$, p-

424 value $<0.01)$ D) echinenone $(F(2,53)=7.3$, p-value $<0.01)$ E) okenone $(F(2,53)=10.1$, p-

425 value $<0.01) \mathrm{F})$ canthaxanthin $(\mathrm{F}(2,53)=26.8$, p-value $<0.01) \mathrm{G})$ chlorophyll $b(2$ outliers

426 removed in the Post-HTM zone $)(\mathrm{F}(2,53)=6.5$, p-value $<0.01) \mathrm{H})$ fucoxanthin $(\mathrm{F}(2,53)=52.1$,

427 p-value $<0.01)$ I) diatoxanthin $(F(2,53)=47.1$, p-value $<0.01) \mathrm{J})$ myxoxanthophyll $(\mathrm{F}(2,53)=$

$42822.9, \mathrm{p}$-value $<0.01)$. Asterisks indicate zones that are significantly different based on post-hoc

429 t-tests (Table 2). Pre-HTM zone omitted due to the small number of samples in this zone.

431 Table 3 Summary of the one-way ANOSIM pair-wise tests (Bray-Curtis dissimilarity) on 432 Charland Lake diatom relative abundances, diatom concentrations, and HPLC data between the 433 pollen-derived climate zones. Significance levels indicated in brackets. Bold cells indicate 434 significance (999 permutations).

435

\begin{tabular}{lllllll}
\hline & $\begin{array}{l}\text { Diatom } \\
\text { Relative } \\
\text { Abundance }\end{array}$ & $\begin{array}{l}\text { Diatom Relative } \\
\text { Abundance }(\text { sqrt })\end{array}$ & $\begin{array}{l}\text { Diatom } \\
\text { Concentration }\end{array}$ & $\begin{array}{l}\text { Diatom } \\
\text { Concentration } \\
\text { (sqrt) }\end{array}$ & $\begin{array}{l}\text { HPLC } \\
\text { concentration }\end{array}$ & $\begin{array}{l}\text { HPLC } \\
\text { concentration } \\
\text { (sqrt) }\end{array}$ \\
\hline Global R & $0.25(0.001)$ & $0.28(0.001)$ & $0.23(0.001)$ & $0.24(0.001)$ & $0.23(0.001)$ & $0.31(0.001)$ \\
\hline $\begin{array}{l}\text { Modern, } \\
\text { Post-HTM }\end{array}$ & $0.02(0.294)$ & $0.08(0.12)$ & $\mathbf{0 . 2 1 ( 0 . 0 0 8 )}$ & $\mathbf{0 . 2 7 ( 0 . 0 0 3 )}$ & $\mathbf{0 . 3 9 ( 0 . 0 0 1 )}$ & $\mathbf{0 . 5 8 ( 0 . 0 0 1 )}$ \\
\hline
\end{tabular}




\begin{tabular}{lllllll}
$\begin{array}{l}\text { Modern, } \\
\text { HTM }\end{array}$ & $0.35(0.002)$ & $0.37(0.001)$ & $0.3(0.002)$ & $0.27(0.002)$ & $0.12(0.1)$ & $0.21(0.017)$ \\
$\begin{array}{l}\text { Post- } \\
\text { HTM, }\end{array}$ & $0.34(0.001)$ & $0.33(0.001)$ & $0.22(0.001)$ & $0.24(0.001)$ & $0.21(0.001)$ & $0.27(0.001)$ \\
HTM & & & & & & \\
\hline
\end{tabular}

437 Table 4. Summary of the one-way SIMPER tests (Bray-Curtis dissimilarity) on Charland Lake 438 diatom relative abundances, diatom concentrations, and HPLC data between pollen-derived 439 climate zones. Percent contribution of driving taxa indicated in brackets.

\begin{tabular}{lllllll}
\hline & $\begin{array}{l}\text { Diatom } \\
\text { Relative } \\
\text { Abundance }\end{array}$ & $\begin{array}{l}\text { Diatom } \\
\text { Relative } \\
\text { Abundance } \\
\text { (sqrt) }\end{array}$ & $\begin{array}{l}\text { Diatom } \\
\text { Concentration }\end{array}$ & $\begin{array}{l}\text { Diatom } \\
\text { Concentration } \\
\text { (sqrt) }\end{array}$ & $\begin{array}{l}\text { HPLC } \\
\text { concentration }\end{array}$ & $\begin{array}{l}\text { HPLC } \\
\text { concentration } \\
\text { (sqrt) }\end{array}$ \\
\hline $\begin{array}{lllll}\text { Modern, Post- } \\
\text { HTM }\end{array}$ & $\begin{array}{l}\text { S. minutulus } \\
(32.8 \%)\end{array}$ & $\begin{array}{l}\text { D. stelligera } \\
(18.8 \%)\end{array}$ & $\begin{array}{l}\text { S. minutulus } \\
(46.2 \%)\end{array}$ & $\begin{array}{l}\text { S. minutulus } \\
(26.7 \%)\end{array}$ & Lutein (29.0\%) & $\begin{array}{l}\text { Myxoxanthophy } \\
(17.4 \%)\end{array}$ \\
\hline Modern, HTM & S. minutulus & S. minutulus & S. minutulus & S. minutulus & Lutein (27.9\%) & Diatoxanthin \\
$(129.7 \%)$ & $(17.1 \%)$ & $(46.0 \%)$ & $(26.3 \%)$ & & (17.4\%) \\
\hline Post-HTM, & S. minutulus & S. minutulus & S. minutulus & $\begin{array}{l}\text { D. stelligera } \\
(17.8 \%)\end{array}$ & Lutein $(40.2 \%)$ & Lutein $(22.3 \%)$ \\
HTM & $(22.8 \%)$ & $(14.6 \%)$ & $(27.7 \%)$ & & & \\
\hline
\end{tabular}

Diatoms

Application of pollen climate zones to the diatom assemblages of Charland Lake showed

446 that diatom concentrations were low in both the Pre-HTM zone and the second clay band, but

447 increased in the organic layer between the clay bands during the HTM to $\sim 23 \times 10^{8}$ valves per

448 gram dry weight (Figure 7). Diatom concentrations also increased after the second clay band and

449 remained relatively stable between $284-145 \mathrm{~cm}$ (range $\sim 9$ to $21 \times 10^{8}$ valves per gram dry

450 weight). The scale-to-diatom index was low within both clay bands, with an increase in scaled

451 chrysophyte abundance in the intervening organic layer. The abundance of scaled chrysophytes

452 increases during the second clay band and continued to increase throughout the HTM and Post-

453 HTM zones. After a Post-HTM zone peak, scaled chrysophyte abundance declined into the

454 Modern zone and remained low to the top of the core (Figure 7). [insert Figure 7.] 
456 Figure 7. Relative abundance of dominant ( $>5 \%$ found in 3 sections of the core) diatom taxa in 457 Charland Lake arranged by age (cal yr BP). The diatom taxa are arranged by their weighted458 average optima based on cumulative depth in the core. The scale-to-diatom index and total 459 diatom concentrations (valves/g dry weight $\mathrm{x} 10^{8}$ ) are also shown. Darker zones in Sediment

460 Type represent organic sedimentation in the piston core. Layered zones represent clay deposits.

461 The dotted lines indicate the pollen-derived climate zones from Figure 3.

The largest shift in diatom assemblages occurred after the second clay band, before the 464 boundary of the HTM and Post-HTM zones. Prior to this point, the Pre-HTM and HTM zones 465 were predominated by benthic taxa, while the Post-HTM and Modern zones were composed 466 mainly of planktonic taxa. Only one sample from the Pre-HTM zone contained enough diatoms 467 for enumeration so this zone was removed from the analysis.

468 HTM taxa prior to the second clay band included Staurosira construens and Staurosirella 469 pinnata. Lindavia intermedia appeared as an important taxon immediately before and after this 470 clay band. After the resumption of organic sedimentation, Stephanodiscus minutulus was the 471 predominant taxon for the remainder of the zone. The importance of S. minutulus increased in 472 the Post-HTM -zone and remained common until $\sim 220 \mathrm{~cm}$ when relative abundance of 473 Discostella stelligera increased. This pattern was reversed at $\sim 105 \mathrm{~cm}$. Diatom assemblages 474 within the Modern zone were composed largely of S. minutulus and Stephanodiscus parvus; 475 however, D. stelligera abundance increased again at $\sim 70 \mathrm{~cm}$ until it became a subdominant 476 species at the top of the core (Figure 7). 
The difference in diatom assemblages between the four pollen-derived climate zones

478 were assessed using ANOSIM tests. The null hypothesis of no difference between diatom

479 assemblages in the HTM, Post-HTM, and Modern zones was rejected in two of the pair-wise

480 tests comparing the HTM zone to the Post-HTM zone and the HTM zone to the Modern zone

481 (Table 3). SIMPER tests identified S. minutulus as the predominant species contributing to $\sim 23 \%$

482 of the difference in species composition between the HTM and Post-HTM zones (Table 4).

483 Similarly, there was a significant shift in species composition between the HTM and Modern

484 zones with S. minutulus driving species change and contributing to $\sim 30 \%$ of the difference in 485 species composition (Table 4).

Discussion

The HTM in northeast Ontario took place from $~ 7800-4500$ cal yr BP based on large 489 changes in pollen data that suggest elevated temperatures. Average temperature reconstructions 490 from the pollen assemblages in Charland Lake showed that the climate was $\sim 1.5-2.0^{\circ} \mathrm{C}$ warmer 491 than the modern day. In this context, the 'modern day' refers to the top of our piston core which 492 corresponds to $\sim 1950$. All discussion referring to 'the modern day' or 'present day' relate to this 493 time frame. Algal response to climate change over the Holocene of this region was variable and 494 somewhat unexpected as the warm HTM zone did not experience the greatest amount of algal 495 abundance. Instead, the cooler Post-HTM and Modern zones showed increased algal production 496 which may be related to various indirect climate and landscape effects. These effects, along with 497 more thorough interpretations of pollen and algal data, are discussed in the forthcoming sections. 
Pre-HTM zone ( 8200-7800 cal yr BP)

501 The climate during this interval was cooler than present as is shown in the temperature

502 reconstruction (Figure 3). This inference of cooler temperatures arises because of the

503 predominance of Picea pollen, combined with a relatively low amount of Pinus sp. pollen.

504 Thermophilous taxa, such as deciduous hardwood trees, were rare in the Pre-HTM zone, further

505 contributing to the inference of cool conditions. In addition, the landscape was likely poorly

506 developed with low vegetation cover and immature, highly inorganic soils, as inferred by the

507 relatively high abundances of ferns and other spore producing plants. It is likely that the boreal

508 forest had not completely colonized the watershed of Charland Lake so soon after the draining of

509 Glacial Lake Ojibway 8200 cal yr BP (Liu, 1990; Prentice et al., 1991).

511 HTM zone ( 7800-4500 cal yr BP)

512 Reconstructed temperature shows a sharp increase by $\sim 2{ }^{\circ} \mathrm{C}$ at the onset of this zone

$513 \sim 7800$ cal yr BP. This climate shift is most driven in the decline of Picea and the increase in $P$.

514 banksiana/resinosa, followed by increases in P. strobus and Cupressaceae at $\sim 6000$ cal yr BP.

515 This is similar to patterns recorded in the mid-Holocene of Lake Six as described by Liu (1990).

516 This two-phase HTM likely represents an increase in precipitation levels after $\sim 6000$ cal yr BP

517 as inferred by increase of Cupressaceae.

518 Interpretation of the Cupressaceae peak is difficult, as this pollen morphotype cannot be

519 easily distinguished between Juniperus and Thuja based on morphological characteristics alone

520 (McAndrews, 1973; Yu, 1997). As Juniperus and Thuja are indistinguishable as pollen types,

521 and the two genera have differing climatic optima, we have elected to remove Cupressaceae

522 from our temperature reconstructions. It is for this reason as well, that we did not attempt to 
523 reconstruct annual precipitation over the Holocene based on the pollen in the Charland Lake

524 core. Juniperus is known to prefer dry habitats, while Thuja prefers wetter conditions (Johnston,

525 1990; Yu et al., 1996; Yu 1997). Nonetheless, we infer that Cuppressaceae were composed

526 mainly of Thuja at Charland Lake due to the presence of Thuja stomata observed on pollen

527 slides. This interpretation agrees with that of Liu (1990) who inferred that Thuja represented

528 most Cupressaceae pollen at Lake Six based on the occurrence of fossil Thuja seeds. Carcaillet et

529 al. (2001) also inferred the presence of Thuja rather than Juniperus because charcoal analysis

530 shows that forest fire frequency did not increase in the area during the HTM which would be

531 consistent with a wetter, Thuja-rich environment.

532 Pinus strobus, which increased in relative abundance alongside Cupressaceae likely

533 expanded northward from the mixed Great Lakes-St. Lawrence forest as average temperature

534 increased (Terasmae and Anderson, 1970; Richard, 1980; Bartlein et al., 1984, Liu, 1990; Hall et

535 al., 1994). Concomitant changes in P. strobus and Cupressaceae during the HTM also argues for

536 the presence of Thuja, as competition for the drier upland areas would not have allowed the

537 coexistence of Juniperus and P. strobus (Liu, 1990). Thuja would have had minimal habitat

538 competition with $P$. strobus, allowing the species to coexist (Fowells, 1965; Liu, 1990). It is

539 therefore likely that Thuja proliferated in the widespread wetlands of the Clay Belt lowlands,

540 while $P$. strobus occupied dry upland sites (Liu, 1990).

541 We infer that the HTM manifested in two phases in the Charland Lake region. The first

542 phase, from $\sim 7500-6000$ cal yr BP, saw the increase of Pinus banksiana/resinosa and increased

543 average temperature $\sim 2{ }^{\circ} \mathrm{C}$ compared to the previous zone. The second phase occurred from

$544 \sim 6000-4500$ cal yr BP and experienced increases in P. strobus, a large increase in Thuja-inferred

545 Cupressaceae, and a further increase in temperature by $\sim 0.5-1.0^{\circ} \mathrm{C}$ to a maximum of $\sim 3^{\circ} \mathrm{C}$. This 
546 reconstruction makes the maximum $\mathrm{HTM}$ temperature $\sim 1.5-2.0{ }^{\circ} \mathrm{C}$ warmer than current

547 conditions, a value which is in line with temperature estimates provided by climatic modelling

548 for this region (Renssen et al., 2009, 2012). We also postulate that the second phase of the HTM

549 was wetter than present in this region, as Thuja would have inhabited widespread wetlands

550 which developed during this time. This interpretation is consistent with Prentice et al. (1991)

551 whose precipitation reconstructions of the Holocene of eastern North America shows an increase

552 in annual precipitation in northeast Ontario after $\sim 6000 \mathrm{cal}$ yr BP.

554 The Post-HTM zone ( 4500-1700 cal yr BP)

555 The Post-HTM zone was a transitional time between the warmer HTM and cooler

556 modern climate regimes. The reconstructed temperature shows a decline in temperature from the 557 maximum Holocene value of $\sim 3.0{ }^{\circ} \mathrm{C}$ at $\sim 5000 \mathrm{cal}$ yr BP to $\sim 1.5{ }^{\circ} \mathrm{C} \sim 4500 \mathrm{cal} \mathrm{yr} \mathrm{BP}$. Average

558 temperature remained around $1.5^{\circ} \mathrm{C}$ for the majority of this zone. Floristically, this zone saw

559 clear decreases in P. strobus and Cupressaceae and increases in Picea and Pinus

560 banksiana/resinosa. In addition, the observed increase in Betula may suggest increased fire

561 activity and drier conditions which in turn would not allow for the continued high abundance of

562 Thuja after $\sim 3700$ cal yr BP (Carcaillet et al., 2001) which is shown in the concentration diagram

563 (Supplemental Figure 3).

564

565 Modern zone ( 1700-0 cal yr BP)

566 During the Modern interval, Picea increased, while P. strobus declined further,

567 contributing to the inferred decrease in average temperature to $\sim 1.0{ }^{\circ} \mathrm{C}$. Betula and other

568 common and uncommon arboreal tree types remained largely unchanged throughout this period. 
569 It is quite likely that this climate zone experienced an increase in precipitation as represented by

570 the increased abundance in Picea and decrease in P. banksiana/resinosa (Liu, 1990; Prentice et

571 al., 1991).

572

573 Lake and algal responses to Holocene climate change

574 Definition of climate zones based on historical changes in terrestrial vegetation allows us 575 to evaluate both how regional climate variation may have affected the linkage between land and

576 water, and the responses of past changes in the production and community composition of

577 aquatic primary producers. Here we evaluate changes in community composition of phototrophs 578 (using fossil pigments and diatom assemblages) better understand changes in climate on aquatic 579 environments.

Pre-HTM zone ( $8200-7800$ cal yr BP)

Northeastern Ontario was inundated by Glacial Lake Ojibway during the early Holocene.

583 This glacial lake deposited thick clay layers which form the Great Clay Belt in the Cochrane

584 District of northern Ontario before draining into the Tyrrell Sea $~ 8200$ cal yr BP (Veillette, 1994;

585 Roy et al., 2011, 2015) resulting in the formation of Charland Lake. Algal production (both

586 pigments and diatoms) was too low to be detected or analyzed statistically in the Pre-HTM zone.

587 This may be due to the deposition of the first clay layer during this time. Clastic or mineral-rich

588 sedimentation is common in the early ontogeny of post-glacial boreal lakes (Liu, 1990; Teller et

589 al., 2018) and is known to interrupt fossil preservation and signals of algal abundance when

590 sedimentary organic matter is extremely low (Leavitt and Hodgson, 2001; Bunting et al., 2010). 
HTM zone ( 7800-4500 cal yr BP)

The climate rapidly warmed at the onset of this zone as shown in the temperature

594 reconstruction based on pollen (Figure 3), but pollen data suggests a two-phase warming event;

595 first warm and dry conditions followed by warm and wet conditions. Charland Lake continued to

596 experience major clastic input at the beginning of this zone, although microfossils from algae

597 and cyanobacteria begin to appear at this time. High abundance of S. construens and S. pinnata

598 during the early HTM suggests low-light or turbid conditions (Haworth, 1976; Bradshaw et al.,

599 2000; Fritz et al., 2004) consistent with high clastic influx. These benthic diatoms are known to

600 be tolerant of low-light environments (Punning and Puusepp, 2007; Kingsbury et al., 2012)

601 which, along with the low concentrations of both diatoms and pigments, suggests an

602 unproductive and light-limited environment. Influx of clastic material in Charland Lake may

603 reflect high rates of terrestrial erosion from the undeveloped landscape. The young forest

604 surrounding Charland Lake was likely open during the early HTM, favoring high rates of

605 weathering and transport of clay particles to the lake (Dearing, 1983; Dearing and Foster, 1986;

606 Almquist-Jacobson, 1992).

607 Deposition of organic matter begins in the HTM, although algal fossils remain rare until

$608 \sim 7000 \mathrm{cal}$ yr BP (Figure 5). The appearance of fossil pigments from many but not all groups was

609 likely a response to HTM warming, soil development, and the influx of organic matter which

610 would have created anoxic sediments which provided a better environment for pigment

611 preservation (Leavitt, 1993; Leavitt and Hodgson, 2001; Leavitt et al., 2003). Consistent with

612 this pattern, the ratio of chlorophyll $a$ to phaeophytin $a$ suggests a high degree of pigment

613 preservation (Leavitt and Hodgson, 2001) following the period of high clastic influx. Lower light 
614 penetration during the final period of fine inorganic matter influx may have reduced photo-

615 oxidation of pigments and favoured elevated fossil concentrations (Furlong and Carpenter, 1988;

616 Hurley and Armstrong, 1990, 1991; Leavitt, 1993). Finally, inferred low water-levels (based on

617 the high abundances of benthic diatoms) may have favoured development of benthic mats of

618 chlorophytes and cyanobacteria (as canthaxanthin). Typically, labile pigments (such as Chl $a$ ) are

619 preserved better if they are produced in benthic mats (Leavitt et al., 1994b; Leavitt et al., 2003).

620 At $\sim 6000$ cal yr BP, Thuja-inferred Cupressaceae increases rapidly, signifying the onset

621 of wet conditions (Figure 3). Several major phycological and sedimentological changes

622 coincided with this wetter climate. First, elevated organic matter sedimentation persisted until

$623 \sim 6100 \mathrm{cal}$ yr BP and was characterized by increased pigment concentrations, elevated relative

624 abundance of planktonic diatoms, and an increase in chrysophyte scales indicative of deeper lake

625 conditions (Zeeb and Smol, 2001; Figure 5, 7). Contemporaneous with increased temperatures

626 and lake-levels, landscape stabilization was occurring, as indicated by a hiatus in clastic

627 sedimentation which suggests forest closure and reduced erosion (Liu, 1990). The transition to

628 gyttja-based sediments also suggests the presence of soluble nutrients leaching from fresh,

629 organic soils (Liu, 1990).

630 Organic sedimentation was interrupted by the deposition of the second clay layer $\sim 6000$

$6315500 \mathrm{cal} \mathrm{yr} \mathrm{BP}$, at which time concentrations of phototrophic fossils declines and diatom

632 assemblages reverted to benthic taxa. Paradoxically, high Cupressaceae pollen abundance

633 suggests a wet climate and high lake-levels. We propose that water levels increased sufficiently

634 to let Charland Lake join with surrounding aquatic ecosystems, including nearby Fredrick House

635 Lake, a site which is only $\sim 2 \mathrm{~m}$ below the study basin. As Fredrick House Lake is turbid,

636 conjoined waters may have introduced clastic material from the Fredrick House Lake catchment 
637 into Charland Lake. Aquatic conditions in this second clay band were similar to those seen in the

638 early HTM period, where diatom assemblages were composed mainly of benthic species and

639 pigment and frustule concentrations were low.

640 After $\sim 5500$ cal yr BP, organic sedimentation resumed with no noticeable change in

641 pollen assemblages. In contrast, diatom assemblages rapidly shifted to planktonic taxa, similar to

642 that observed within the organic layer between clay bands, but with elevated abundance of the

643 eutrophic taxon Stephanodiscus minutulus. Stephanodiscus taxa are common in productive

644 waters (Cumming et al., 2015) and compete for silica better than other planktonic species

645 (Mechling and Kilham, 1982). Past research has associated higher water levels with lower Si:P

646 ratios and an associated dominance of Stephanodiscus (Kilham and Kilham, 1990). The

647 eutrophication may reflect increased internal loading of nutrients from anoxic sediments, as

648 indicated by the presence of okenone, a pigment from purple sulfur bacteria. These prokaryotic

649 taxa are obligate anaerobes and are present only when light penetrates to anoxic environments

650 (see Leavitt et al., 1989). Regardless of the mechanism, the increase in nutrients must have been

651 relatively minor, as neither frustule concentration nor that of most pigments suggests a strong

652 increase in primary production during this period.

654 Post-HTM zone ( 4500-1700 cal yr BP)

655 Reconstructed average temperature shows that this zone experienced a cooler climate 656 than the HTM but was still warmer than modern conditions. Algal groups responded to these

657 climate changes; both diatom frustules and pigment concentrations increased moderately, 658 possibly signaling an overall increase in primary production. The eutrophic S. minutulus

659 continued to dominate the diatom assemblage until $\sim 3900$ cal yr BP when it was replaced by the 
660 more oligotrophic Distostella stelligera (Figure 7). Presently, we are uncertain whether observed 661 changes in fossil patterns reflect direct effects of climate, or indirect variation in lake structure

662 and function, such as a change in thermal stratification. For example, increased abundance of $D$.

663 stelligera has been shown to correspond with a longer period of stratification (Dean et al., 1994;

664 Bradbury et al., 2002; Wiltse et al., 2016) and a shallow mixing depth (Saros et al., 2012). This

665 interpretation is supported by changes in the chrysophyte scale-to-diatom index, as chrysophytes

666 have a competitive advantage over diatoms when the water column is strongly stratified (Eimers

667 et al., 2009). An increase in the abundance of chrysophytes has also been related to less

668 eutrophic conditions, which agrees with an increase in D. stelligera (Reynolds, 1988; Brabury et 669 al., 2002).

670 Despite a trend towards oligotrophication as suggested by diatoms, interpretation of fossil 671 pigment data suggests an increase in algal production during this period. Several mechanisms 672 could underlie this pattern. First, increased thermal stratification can lead to the formation of 673 metalimnetic blooms which tend to be over-represented in lake sediments (Leavitt et al., 1989;

674 Leavitt and Hodgson, 2001). Alternately, changes in the seasonality of lake stratification could

675 favor production of phototrophic groups other than diatoms. For example, both lutein-

676 zeaxanthin, a stable indicator of green algae and cyanobacteria, and alloxanthin, a stable

677 indicator of cryptophytes, had significantly higher concentrations (Figure 6) during this period 678 compared to the HTM zone. Lower concentrations of other pigments from cyanobacteria (e.g., 679 echinenone, canthaxanthin, myxoxanthophyll) suggest limited contributions of those taxa to the 680 lutein-zeaxanthin signal (Brock et al., 2006). Both cryptophytes and chlorophytes (together 681 'flagellates') tend to replace negatively buoyant diatoms during periods of thermal stratification, 682 due to their motility (Hickman, 1974; Reynolds, 1984). As such, higher concentrations of these 
683 algal groups suggest a longer period of thermal stratification during the Post-HTM period and,

684 perhaps, reduced diatom recruitment, which favoured growth of other phytoplankton groups,

685 such as cryptophytes and chlorophytes.

686

687 Modern zone ( 1700-0 cal yr BP)

688 At Charland Lake, the Modern period of northeastern Ontario was characterized by a cold 689 and wet environment based on the decrease of P. strobus and the dominance of Picea. However, 690 algal proxies from Charland Lake suggest the onset of more eutrophic conditions as

691 concentrations of diatoms, and pigments characteristic of diatoms (fucoxanthin, diatoxanthin),

692 were highest during this period. Statistical analyses of individual pigments revealed that

693 canthaxanthin and okenone increased significantly (Figure 6), indicating an abundance of

694 colonial cyanobacteria and purple sulfur bacteria, respectively (Leavitt and Hodgson, 2001).

695 Given that the Chl a:pheophytin ratio declined slightly prior to the Modern period (Figure 5), but

696 okenone increased, we infer that these changes may reflect in part a minor change in the

697 preservation environment at Charland Lake. However, because this interval is also marked by the

698 first occurrence of chemically-robust myxoxanthophyll, a ubiquitous compound in colonial

699 cyanobacteria, we infer that the Modern zone has also been more productive than previous

700 periods.

701 The movement towards colder conditions during this period may have also promoted

702 more lake mixing and less-stable thermal stratification, allowing some algal species, such as $S$.

703 minutulus, to proliferate (Reynolds and Reynolds, 1985; Kilham et al., 1986; Makulla and

704 Sommer, 1993; Bradbury et al., 2002). Growth requirements of Stephanodiscus species may

705 have been largely satisfied by the regeneration of phosphorus from nutrient-dense water to the 
706 photic zone during spring circulation, resulting in large blooms of S. minutulus and S. parvus

707 (Kilham and Kilham, 1978; Bradbury et al., 2002). The inference of extended periods or

708 vigorous lake-mixing is also supported by the decrease in the chrysophyte scale-to-diatom index,

709 further suggesting less stratification (Reynolds, 1984; Rott, 1984).

710 Interpretation of the influence of climate on canthaxanthin (Nostocales cyanobacteria)

711 and okenone (purple sulfur bacteria) is not straightforward, as both of these algal groups would

712 be expected to decrease under cooler and wet conditions (Lami et al., 2009). Okenone is found in

713 anaerobic purple sulfur bacteria which prefer the oxic-anoxic interface in lakes (Massé et al.,

714 2002), hence higher concentrations of okenone can be related to seasonal anoxia in lakes

715 (Maheux et al., 2016). On the other hand, low concentrations of purple sulfur bacteria have been

716 related to cool conditions, likely coupled with increased mixing of the water column (Schmidt et

717 al., 2002). Overall, concentrations of okenone are much lower than those seen in meromictic or

718 strongly stratified ecosystems (Leavitt et al., 1989) and suggests the presence of only seasonal

719 (summer) anoxia, perhaps restricted to deep littoral sediments. Furthermore, canthaxanthin, an

720 indicator of Nostocales cyanobacteria, is often associated with high nutrients in the water column

721 (Kleppel et al., 1988; Lami et al., 2009), but can also be a marker of $\mathrm{N}_{2}$ fixation (Hayes et al.,

722 2018). One possibility is that the Modern period experienced in an influx of dissolved organic

723 matter (DOM) which would have helped proliferate the heterotrophic growth of the

724 cyanobacteraial groups (Stevenson et al., 2016). Regardless it seems likely that factors other than

725 climate must be considered to understand how limnologic conditions became ideal for these

726 groups in the Modern period.

727

728 Conclusions 
730 from $\sim 7800-4500$ cal yr BP. The onset of warmth is $\sim 1000$ years later than recorded in

731 northwest Ontario (Moos et al., 2009; Moos and Cumming, 2011, 2012; Karmakar et al., 2015a,

732 2015b). Differences between our findings and Liu's (1990) may be due to the more rigorous

733 carbon dating model used in our study as our pollen analysis agrees with Liu's (1990) quite well.

734 Analysis of fossil pollen showed that the HTM in northeastern Ontario was warm and dry from

$735 \sim 7500-6000$ cal yr BP and then become wet from $\sim 6000-4500$ cal yr BP as indicated by the high

736 abundance of Thuja-inferred Cupressaceae pollen. Algal abundance was variable over the

737 Holocene, as inferred from both fossil pigment and diatom concentrations, apparently responding

738 mainly to variation in the linkage between land and water.

739 This work represents one of the first investigations in northeast Ontario to assess the

740 relationship between climate and in-lake production during the Holocene Epoch. Overall, the

741 interaction between climate and limnological conditions were complex within Charland Lake,

742 providing a striking comparison with lakes in northwest Ontario at millennial time scales. In

743 general, we demonstrate that limnological conditions were more optimal for algae over the last

$744 \sim 4500$ years than in the preceding millennia. This pattern is in stark contrast to those seen in

745 lakes from northwest Ontario, where paleolimnological studies have linked the warmer HTM to

746 enhanced lake-water production (Moos and Cumming, 2009; Karmakar et al., 2015b). In

747 Charland Lake, such changes were evident, but small in comparison, and did not indicate the

748 warmer temperatures of the HTM directly influenced lake-water production. These findings

749 suggest indirect climate effects, such as changes in thermal stratification and mixing, may be

750 more influential on algal production in some lakes in northeast Ontario. If this were broadly true,

751 it suggests that lakes in northeast Ontario may respond differently to future climate change 
752 compared to lakes elsewhere in northern Ontario, and that the response and susceptibility of

753 lakes to climate change can vary across an ecozone.

\section{Acknowledgements}

756 The authors thank the LacCore team at the University of Minnesota and Tom Brown at

757 the Lawrence Livermore National Laboratory for sample preparation and carbon dating. Thanks

758 also to Matthew Peros for his helpful advice on pollen sample preparation and to Kathleen Laird

759 for her assistance with diatom processing and taxonomy. We thank Deirdre Bateson at U. Regina

760 for analysis of fossil pigments. Special thanks to Graham Mushet, Cécilia Barouillet, and Gladys

761 Kong for help in the field. Additional thanks are given to two anonymous reviewers whose

762 comments greatly improved this manuscript. Funding for this project was provided by an

763 NSERC Discovery Grant to BFC, SFL and PRL, an NSERC PGS-D scholarship to CACG, and

764 funding from Canada Research Chair and Canada Foundation for Innovations programs.

\section{References}

Almquist-Jacobson H, Almendinger JE and Hobbie S (1992). Influence of terrestrial vegetation on sediment-forming processes in kettle lakes of west-central Minnesota. Quaternary Research 38: 103-116.

Bartlein PJ, Webb, TIII and Fleri E (1984) Holocene climatic change in the northern Midwest: pollen-derived estimates. Quaternary Research 22: 361-374.

Bassett IJ, Crompton CW and Parmelee JA (1978) An atlas of airborne pollen grains and common fungus spores of Canada. Hull: Canada Department of Agriculture, Ministry of Supply and Services Canada.

Bennett KD and Willis KJ (2001) Pollen. In: Smol JP, Birks HJB and Last WM (eds) Tracking Environmental Change using Lake Sediments, Vol. 3: Terrestrial, algal, and siliceous indicators. Dordrecht: Kluwer Academic Publishers, pp.5-32. 
Blaauw M and Christen JA (2011) Flexible paleoclimate age-depth models using an autoregressive gamma process. Bayesian Analysis 6: 457-474.

Bond G, Kromer B, Beer J, Muscheler R, Evans MN, Showers W, Hoffman S, Lotti-Bond R, Hajdas I and Bonani G (2001) Persistent solar influence on North Atlantic climate during the Holocene. Science 294: 2130-2136.

Bradbury P, Cumming BF and Laird KR (2002) A 1500-year record of climatic and environmental change in Elk Lake, Minnesota III: measures of past primary productivity. Journal of Paleolimnology 27: 321-340.

Bradshaw EG, Jones VJ, Birks HJB and Birks HH (2000) Diatom responses to late-glacial and early-Holocene environmental changes at Kråkenes, western Norway. Journal of Paleolimnology 23: 21-34.

Briner JP, McKay NP, Axford Y, Bennike O, Bradley RS, de Vernal A, Fisher D, Francus P, Frechette B, Gajewski K, Jennings A, Kauffman DS, Miller G, Rouston C and Wagner B (2016) Holocene climate change in Arctic Canada and Greenland. Quaternary Science Reviews 147: 340-364.

Brock CS, Leavitt PR, Schindler DE, Johnson SP and Moore JW (2006) Spatial variability of stable isotopes and fossil pigments in surface sediments of Alaskan coastal lakes: constraints on quantitative estimates of past salmon abundance. Limnology and Oceanography 51: 1637-1647.

Brown TA, Nelson DE, Mathewes RW, Vogel JS and Southon JR (1989) Radiocarbon dating of pollen by accelerator mass spectrometry. Quaternary Research 32: 1205-1212.

Bunting L, Leavitt PR, Weidman RP and Vinebrooke RD. (2010) Regulation of the nitrogen biogeochemistry of mountain lakes by subsidies of terrestrial dissolved organic matter and the implications for climate studies. Limnology and Oceanography 55: 333-345.

Carcaillet C, Bergeron Y, Richard PJ, Frechette B, Gauthier S and Prairie YT (2001) Change of fire frequency in the eastern Canadian boreal forests during the Holocene: does vegetation composition or climate trigger the fire regime? Journal of Ecology 89: 930946.

Carlson AE, LeGrande AN, Oppo DW, Came RE, Schmidt GA, Anslow FS, Licciardi JM and Obbink EA (2008) Rapid early Holocene deglaciation of the Laurentide ice sheet. Nature Geoscience 1: 620-624.

Clarke KR and Warwick RM (1994) Similarity-based testing for community pattern: the twoway layout with no replication. Marine Biology 118: 167-176. 
812 Cumming BF, Wilson SE, Hall RI and Smol JP (1995) Diatoms from British Columbia (Canada) 813 Lakes and Their Relationship to Salinity, Nutrients, and Other Limnological Variables. $814 \quad$ Bibliotheca Diatomologica 31: 1-207.

815 Cumming BF, Laird KR, Gregory-Eaves I, Simpson KG, Sokal MA, Nordin R and Walker IR

816

817

818

819

820

821

822

823

824

825

826

827

828

829

830

831

832

833

834

835

836

837

(2015) Tracking past changes in lake-water phosphorus with a 251-lake calibration dataset in British Columbia: tool development and application in a multiproxy assessment of eutrophication and recovery in Osoyoos Lake, a transboundary lake in Western North America. Frontiers in Ecology and Evolution 3: 1-18.

Dean WE, Bradbury JP, Anderson RY, Bader LR and Dieterich-Rurup KV (1994) A highresolution record of climatic change in Elk Lake, Minnesota for the last 1500 years. U.S. Geological Survey. Report no. 94-578.

Dearing JA (1983) Changing patterns of sediment accumulation in a small lake in Scania, southern Sweden. Hydrobiologia 103: 59-64.

Dearing JA and Foster IDL (1986) Lake sediments and paleohydrological studies. In Berglund BE (ed) Handbook of Holocene Palaeoecology and Palaeohydrology: Wiley, pp.67-90.

Douglas MSV and Smol JP (1999) Freshwater diatoms as indicators of environmental change in the High Arctic. In Stoermer E. and Smol JP (eds) The Diatoms: Applications for the Environment and Earth Sciences: Cambridge University Press, pp.227-244.

Eimers MC, Watmough SA, Paterson AM, Dillon PJ and Yao H (2009) Long-term declines in phosphorus export from forested catchments in south central Ontario. Canadian Journal of Fisheries and Aquatic Sciences 66: 1682-1692.

Environment Canada (2019) Canadian Climate Normals 1981-2010 Station Data. Available at: http://climate.weather.gc.ca/climate_normals/results_1981_2010 e.html?searchType $=$ st

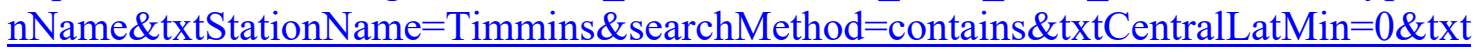
CentralLatSec $=0 \&$ txtCentralLongMin $=0 \&$ txtCentralLongSec $=0 \& \operatorname{stnID}=4180 \& \operatorname{dispBac}$ $\underline{\mathrm{k}=1}$ (Accessed 26 June 2019).

Esri (2015) ArcGIS Desktop: Release 10.5. Redlands, CA: Environmental Systems Research.

Fowells HA (1965) Silvics of forest trees of the United States. Washington D.C.: United States Department of Agriculture Handbook (Number 271).

Fritz SC, Engstrom DR and Juggins S (2004) Patterns of early lake evolution in boreal landscapes: a comparison of stratigraphic inferences with a modern chronosequence in Glacier Bay, Alaska. The Holocene 14: 828-840. 
844 Furlong ET and Carpenter R (1988) Pigment preservation and remineralization in oxic coastal marine sediments. Geochimica et Cosmochimica Acta 52: 87-99.

846

847

848

Glew JR (1989) A new trigger mechanism for sediment samplers. Journal of Paleolimnology 2: 241-243.

Glew JR, Smol JP and Last WM (2001) Sediment core collection and extrusion. In Last WM and Smol JP (eds) Tracking Environmental Change Using Lake Sediments, Basin Analysis Coring and Chronological Techniques, Vol. I. Dordrecht: Kluwer Academic Publishers, pp.73-105.

Goring S, Dawson A, Simpson G, Ram K, Graham R, Grimm E and Williams J (2015) Neotoma: A Programmatic Interface to the Neotoma Paleoecological Database. Open Quaternary 1: $1-17$.

Grimm EC (1987) CONISS: a FORTRAN 77 program for stratigraphically constrained cluster analysis by the method of incremental sum of squares. Computers and Geosciences 13: $13-35$.

Grimm EC (2004) TILIA and TILIA GRAPH Computer Programs Version 2.0.2. Springfield: Illinois State Museum Research and Collections Center.

Hall RI, Duff KE and Quinby PA (1994) A 10,000-year vegetation history of the Temagami Region of Ontario with special emphasis on white pine. Temagami Wilderness Society: $1-10$.

Hall RI, Leavitt PR, Quinlan R, Dixit AS and Smol JP (1999) Effects of agriculture, urbanization and climate on water quality in the northern Great Plains. Limnology and Oceanography 43: 739-756.

Hammer Ø and Harper DAT (2006) Paleontological Data Analysis. Malden: Blackwell Publishing.

Hammer Ø, Harper DAT and Ryan PD (2001) PAST: Palaeontological statistics software package for education and data analysis. Palaeontologica Electronica 4.

Haworth EY (1976) Two late-glacial (Late Devensian) diatom assemblage profiles from northern Scotland. New Phytology 77: 227-56.

Hayes NM, Patoine A, Haig HA, Simpson GL, Swarbrick VJ, Wiik E, and Leavitt PR (2018) Spatial and temporal variation in nitrogen fixation and its importance to phytoplankton growth in phosphorus-rich lakes. Freshwater Biology. doi/10.1111/fwb.13214. 
875

876

877

878

879

880

881

882

883

884

885

886

887

888

889

890

891

892

893

894

895

896

897

898

899

900

901

902

903

904

905

Heiri O, Lotter AF and Lemcke G (2001) Loss on ignition as a method for estimating organic and carbonate content in sediments: reproducibility and comparability of results. Journal of paleolimnology 25: 101-110.

Hickman M (1974) The seasonal succession and vertical distribution of the phytoplankton in Abbot's Pond, North Somerset, U. K. Hydrobiologia 44: 127-147.

Hodgson DA, Wright SW, Tyler PA and Davies N (1998) Analysis of fossil pigments from algae and bacteria in meromictic Lake Fidler, Tasmania, and its application to lake management. Journal of Paleolimnology 19: 1-22.

Hurley JP and Armstrong DE (1990) Fluxes and transformations of aquatic pigments in Lake Mendota, Wisconsin. Limnology and Oceanography 35: 384-398.

Hurley JP and Armstrong DE (1991) Pigment preservation in lake sediments: a comparison of sedimentary environments in Trout Lake, Wisconsin. Canadian Journal of Fisheries and Aquatic Sciences 48: 472-486.

Johnston WF (1990) Thuja occidentalis L. Northern white-cedar. Silvics of North America 1: $580-589$.

Juggins S (2003) C2 Software for ecological and palaeoecological data analysis and visualization User guide 1.3. University of Newcastle, Newcastle, United Kingdom.

Juggins S (2015) Rioja: Analysis of Quaternary Science Data, R package version (0.9-6)

Kapp RO, Davis OK and King JE (2000) Pollen and Spores, second ed. The American Association of Stratigraphic Palynologists.

Karmakar M, Laird KR and Cumming BF (2015a) Diatom-based evidence of regional aridity during the mid-Holocene period in boreal lakes from northwest Ontario (Canada). The Holocene 25: 166-177.

Karmakar M, Leavitt PR and Cumming BF (2015b) Enhanced algal abundance in northwest Ontario (Canada) lakes during the warmer early-to mid-Holocene period. Quaternary Science Reviews 123: 168-179.

Kilham P and Kilham SS (1990) Endless summer: internal loading processes dominate nutrient cycling in tropical lakes. Freshwater Biology 23: 379-389.

Kilham SS and Kilham P (1978) Natural community bioassays: predictions of results based on nutrient physiology and competition. Verhandlungen des Internationalen Verein Limnologie 20: 68-74. 
Kilham P, Kilham SS and Hecky RE (1986) Hypothesized resource relationships among African planktonic diatoms. Limnology and Oceanography 31: 1169-1181.

Kingsbury MV, Laird KR and Cumming BF (2012) Consistent patterns in diatom assemblages and diversity measures across water-depth gradients from eight Boreal lakes from northwestern Ontario (Canada). Freshwater Biology 57: 1151-1165.

Klemm J, Herzschuh U, and Pestryakova LA (2016) Vegetation, climate and lake changes over the last 7000 years at the boreal treeline in north-central Siberia. Quaternary Science Reviews 147: 422-434.

Kleppel GS, Frazel D, Pieper RE and Holliday DV (1988) Natural diets of zooplankton off southern California. Marine Ecology Progress Series 49: 231-241.

Krammer K and Lange-Bertalot H (1991a) Bacillariophyceae. 3: Teil: Centrales, Fragilariaceae, Eunotiaceae, In Ettl H, Gärtner G, Gerloff J, Heynig H and Mollenhauer D (eds) Stuttgart: Süßwasserflora von Mitteleuropa, Band 2/3.

Krammer K and Lange-Bertalot H (1991b) Bacillariophyceae. 4: Teil: Achnanthaceae. In Ettl H, Gärtner G, Gerloff J, Heynig H and Mollenhauer D (eds) Stuttgart: Süßwasserflora von Mitteleuropa, Band 2/4.

Krammer K and Lange-Bertalot H (1988) Bacillariophyceae. 2: Teil: Bacillariaceae, Epithmiaceae, Surirellaceae. In Ettl H, Gärtner G, Gerloff J, Heynig H and Mollenhauer D (eds) Stuttgart: Süßwasserflora von Mitteleuropa, Band 2/2.

Krammer K and Lange-Bertalot H (1986) Bacillariophyceae. 1: Teil: Naviculaceae. In Ettl H, Gärtner G, Gerloff J, Heynig H and Mollenhauer D (eds) Stuttgart: Süßwasserflora von Mitteleuropa, Band 2/1.

Lami A, Musazzi S, Marchetto A, Buchaca T, Kernan M, Jeppesen E and Guilizzoni P (2009) Sedimentary pigments in 308 alpine lakes and their relation to environmental gradients. Advances in Limnology 62: 247-268.

Leavitt PR (1993) A review of factors that regulate carotenoid and chlorophyll deposition and fossil pigment abundance. Journal of Paleolimnology 9: 109-127.

Leavitt PR and Hodgson DA (2001) Sedimentary pigments. In Smol JP, Birks HJB, and Last WM. (eds). Tracking Environmental Change using Lake Sediments, Vol. 3: Terrestrial, algal, and siliceous indicators. Dordrecht: Kluwer Academic Publishers, pp295-325.

Leavitt PR, Carpenter DR, and Kitchell JF (1989) Whole-lake experiments: The annual record of fossil pigments and zooplankton. Limnology and Oceanography 34: 700-717. 
Leavitt PR, Hann BJ, Smol JP, Zeeb BA, Christie CC, Wolfe B and Kling HJ (1994a) Paleolimnological analysis of whole-lake experiments: An overview of results from Experimental Lakes Area Lake 227. Canadian Journal of Fisheries and Aquatic Science 51: $2322-2332$.

Leavitt PR, Schindler DE, Paul AJ, Hardie AK, and Schindler DW (1994b) Fossil pigment records of phytoplankton in trout-stocked alpine lakes. Canadian Journal of Fisheries and Aquatic Science 51: 2411-2423.

Leavitt PR, Vinebrooke RD, Donald DB, Smol JP and Schindler DW (1997) Past ultraviolet radiation environments in lakes derived from fossil pigments. Nature 388: 457-459.

Leavitt PR, Cumming BF, Smol JP, Reasoner M, Pienitz R, and Hodgson D (2003) Climatic control of UV radiation effects on lakes. Limnology and Oceanography 48: 2062-2069.

Levec F (2001) B.A.S.S. 2.0 User Manual. Inventroy, Monitoring, and Assessment, Peterborough.

Liu KB (1990) Holocene paleoecology of the boreal forest and Great Lakes-St. Lawrence forest in northern Ontario. Ecological Monographs 60: 179-212.

Lotter AF, Pienitz R and Schmidt R (1999) Diatoms as indicators of environmental change near arctic and alpine treeline. In Stoermer EF and Smol JP (eds) The Diatoms: Applications for the Environmental and Earth Sciences. Cambridge: Cambridge University Press, pp.205-226.

Maheaux H, Leavitt PR, and Jackson LJ (2016) Asynchronous onset of eutrophication among shallow prairie lakes of the northern Great Plains, Alberta, Canada. Global change biology 22: 271-283.

Makulla A and Sommer U (1993) Relationships between resource ratios and phytoplankton species composition during spring in five north German lakes. Limnology and Oceanography 38: 846- 856.

Margold M, Stokes CR and Clark CD (2018) Reconciling records of ice streaming and ice margin retreat to produce a palaeogeographic reconstruction of the deglaciation of the Laurentide Ice Sheet. Quaternary science reviews 189: 1-30.

Massé A, Pringault O and De Wit R (2002) Experimental study of interactions between purple and green sulfur bacteria in sandy sediments exposed to illumination deprived of nearinfrared wavelengths. Applied and Environmental Microbiology 68: 2972-2981.

McAndrews JH, Berti AA and Norris G (1973) Key to the Quaternary pollen and spores of the 
Great Lakes Region. Toronto: Life Science Miscellaneous Publications.

972 Mechling JA and Kilham SS (1982) Temperature effects on silicon limited growth of the Lake Michigan diatom Stephanodiscus minutus (Bacillariophyceae). Journal of Phycology 18: 199-205.

Moos MT and Cumming BF (2011) Changes in the parkland-boreal forest boundary in northwestern Ontario over the Holocene. Quaternary Science Reviews 30: 1232-1242.

Moos MT and Cumming BF (2012) Climate-fire interactions during the Holocene: a test of the utility of charcoal morphotypes in a sediment core from the boreal region of northwestern Ontario (Canada). International Journal of Wildland Fire, 21: 640-652.

Moos MT, Laird KR and Cumming BF (2005) Diatom assemblages and water depth in Lake 239 (Experimental Lakes Area, Ontario): implications for paleoclimatic studies. Journal of Paleolimnology 34: 217-227.

Moos MT, Laird KR and Cumming BF (2009) Climate-related eutrophication of a small boreal lake in northwestern Ontario: a palaeolimnological perspective. The Holocene 19: 359367.

Navarro L, Harvey AÉ, Ali A, Bergeron Y, and Morin H (2018) A Holocene landscape dynamic multiproxy reconstruction: How do interactions between fire and insect outbreaks shape an ecosystem over long time scales?. PloS one, 13.

Overpeck JT, Webb T and Prentice IC (1985) Quantitative interpretation of fossil pollen spectra: Dissimilarity coefficients and the method of modern analogs. Quaternary Research 23: 87-108.

992

993

994

995

996

997

998

999

1000
Prentice IC, Bartlein PJ and Webb T (1991) Vegetation and climate change in eastern North America since the last glacial maximum. Ecology 72: 2038-2056.

Price DT, Alfaro RI, Brown KJ, Flannigan MD, Fleming RA, Hogg EH, Giardin MP, Lakusta T, Johnston M, McKenne, DW, Pedlar JH, Stratton T, Sturrock RN, Thompson ID, Trofymow JA and Venier LA (2013) Anticipating the consequences of climate change for Canada's boreal forest ecosystems. Environmental Reviews 21: 322-365.

Punning JM and Puusepp L (2007) Diatom assemblages in sediments of Lake Juusa, Southern Estonia with an assessment of their habitat. Hydrobiologia 586: 27-41.

R Core Team (2015) R: A language and environment for statistical computing. 
1001

1002

1003

1004

1005

1006

1007

1008

1009

1010

1011

1012

1013

1014

1015

1016

1017

1018

1019

1020

1021

1022

1023

1024

1025

1026

1027

1028

1029

1030

Reimer PJ, Bard E, Bayliss A, Beck JW, Blackwell PG, Bronk Ramsey C, Buck CE, Edwards RL, Friedrich M, Grootes PM, Guilderson TP, Haflidason H, Hajdas I, Hatté C, Heaton TJ, Hoffmann DL, Hogg AG, Hughen KA, Kaiser KF, Kromer B, Manning SW, Niu M, Reimer RW, Richards DA, Scott ME, Southon JR, Turney CSM and van der Plicht J (2013) IntCal13 and Marine13 radiocarbon age calibration curves 0-50,000 yr cal BP. Radiocarbon 55: 1869-1887.

Renssen H, Seppä H, Heiri O, Roche DM, Goosse H and Fichefet T (2009) The spatial and temporal complexity of the Holocene thermal maximum. Nature Geoscience 2: 411.

Renssen H, Seppä H, Crosta X, Goosse H and Roche DM (2012) Global characterization of the Holocene Thermal Maximum. Quaternary Science Reviews 48: 7-19.

Reynolds, CS (1984) The Ecology of Freshwater Phytoplankton. Cambridge: Cambridge University Press.

Reynolds C (1988) Functional morphology and the adaptive strategies of freshwater phytoplankton. In Sandgren, CD (ed) Growth and reproductive strategies of freshwater phytoplankton. Cambridge: Cambridge University Press, pp.388-433.

Reynolds CS and Reynolds JB (1985) The atypical seasonality of phytoplankton in Crose Mere, 1972: An independent test of the hypothesis that variability in the physical environment regulates community dynamics and structure. British Phycological Journal 20: 227242.

Richard P (1980) Histoire postglaciaire de la végétation au sud du lac Abitibi, Ontario et Québec. Geographie physique et Quaternaire 34: 77-94.

Ritchie JC, Cwynar LC and Spear RW (1983) Evidence from north-west Canada for an early Holocene Milankovitch thermal maximum. Nature 305: 126-128.

Rott E (1984) Phytoplankton as biological parameter for the trophic characterization of lakes. Verhandlungen des Internationalen Verein Limnologie 22: 1078-1085.

Roy M, Dell'Oste F, Veillette JJ, de Vernal A, Hélie J-F and Parent M (2011) Insights on the events surrounding the final drainage of Lake Ojibway based on James Bay stratigraphic sequences. Quaternary Science Reviews 30: 682-692.

Roy M, Veillette JJ, Daubois V and Ménard M (2015) Late-stage phases of glacial Lake Ojibway in the central Abitibi region, eastern Canada. Geomorphology 248: 14-23. 
1031

1032

1033

1034

1035

1036

1037

1038

1039

1040

1041

1042

1043

1044

1045

1046

1047

1048

1049

1050

1051

1052

1053

1054

1055

1056

1057

1058

1059

1060 1061

Rühland K and Smol JP (2005) Diatom shifts as evidence for recent Subarctic warming in a remote tundra lake, NWT, Canada. Palaeogeography, Palaeoclimatology, Palaeoecology 226: 1-16.

Saros JE, Stone JR, Pederson GT, Slemmons KE, Spanbauer T, Schliep A, Cahl D, Williamson CE and Engstrom DR (2012) Climate-induced changes in lake ecosystem structure inferred from coupled neo-and paleoecological approaches. Ecology 93: 2155-2164.

Schmidt R, Psenner R, Müller J, Indinger P and Kamenik C (2002) Impact of late glacial climate variations on stratification and trophic state of the meromictic lake Längsee (Austria): validation of a conceptual model by multi proxy studies. Journal of Limnology 61: 4960 .

Shuman BN and Marsicek J (2016) The structure of Holocene climate change in mid-latitude North America. Quaternary Science Reviews 141: 38-51.

Stevenson MA, McGowan S, Anderson NJ, Foy RH, Leavitt PR, McElarney YR, Engstrom DR and Pla-Rabés $S$ (2016) Impacts of forestry planting on primary production in upland lakes from north-west Ireland. Global Change Biology 22: 1490-1504.

Teller JT, Rühland KM, Smol JP, Mellors TJ, and Paterson AM (2018) Holocene history of Lake of the Woods: Ontario, Manitoba, and Minnesota. GSA Bulletin 130: 3-23.

Terasmae J and Anderson TW (1970) Hypsithermal range extension of white pine (Pinus strobus L.) in Quebec, Canada. Canadian Journal of Earth Sciences 7: 406-413.

Veillette JJ (1994) Evolution and paleohydrology of glacial lakes Barlow and Ojibway. Quaternary Science Reviews 13: 945-971.

Viau AE and Gajewski K (2009) Reconstructing millennial-scale, regional paleoclimates of boreal Canada during the Holocene. Journal of Climate 22: 316-330.

Viau AE, Gajewski K, Sawada MC and Fines P (2006) Millennial-scale temperature variations in North America during the Holocene. Journal of Geophysical Research: Atmospheres 111: doi:10.1029/2005JD006031.

Whitlock C and Bartlein PJ (1997) Vegetation and climate change in northwest America during the past $125 \mathrm{kyr}$. Nature 388: 57-61.

Whitmore J, Gajewski K, Sawada M, Williams JW, Shuman B, Bartlein PJ, Minckley T, Viau AE, Webb T, Shafer S, Anderson PM and Brubaker LB (2005) Modern pollen data 
1062

1063

1064

1065

1066

1067

1068

1069

1070

1071

1072

1073

1074

1075

1076

1077

1078

1079

1080

1081

1082

1083

1084

1085

1086

1087

1088

1089

from North America and Greenland for multi-scale paleoenvironmental applications. Quaternary Science Reviews 24: 1828-1848.

Williams JW, Shuman B, Bartlein PJ, Whitmore J, Gajewski K, Sawada M, Mickley T, Shafer S, Viau AE, Webb T, Anderson B, Brubaker LB, Whitlock C and Davis OK (2006) An atlas of pollen-vegetation-climate relationships for the United States and Canada. American Association of Stratigraphic Palynologists Foundation Dallas, Texas.

Wiltse B, Paterson AM, Findlay DL and Cumming BF (2016) Seasonal and decadal patterns in Discostella (Bacillariophyceae) species from bi-weekly records of two boreal lakes (Experimental Lakes Area, Ontario, Canada). Journal of Phycology 52: 817-826.

Wright HE (1967) A square-rod piston sampler for lake sediments. Journal of Sedimentary Research 37: 975-976.

Wright HE, Mann DH and Glaser PH (1984) Piston corers for peat and lake sediments. Ecology 65: 657-659.

Yu Z (1997) Late Quaternary paleoecology of Thuja and Juniperus (Cupressaceae) at Crawford Lake, Ontario, Canada: pollen, stomata and macrofossils. Review of Palaeobotany and Palynology 96: 241-254.

Yu Z, McAndrews JH and Siddiqi D (1996) Influences of Holocene climate and water levels on vegetation dynamics of a lakeside wetland. Canadian Journal of Botany 74: 1602-1615.

Zeeb BA and Smol JP (2001) Chrysophyte scales and cysts. In: Smol JP, Birks HJB and Last WM (eds) Tracking Environmental Change using Lake Sediments, Vol. 3: Terrestrial, algal, and siliceous indicators. Dordrecht: Kluwer Academic Publishers, pp.203-223.

Supplemental figure 1. A) Activity of ${ }^{210} \mathrm{~Pb},{ }^{214} \mathrm{~Pb},{ }^{214} \mathrm{Bi}$, and ${ }^{137} \mathrm{Cs}$ in the Charland Lake gravity core. B) Constant Rate of Supply (CRS) model inferred ages for the Charland Lake gravity core.

Supplemental figure 2. Broken stick model based on a constrained cluster analysis (CONISS) of abundant pollen taxa ( $>1 \%$ in two or more intervals) from Charland Lake. 
1090 Supplemental figure 3. Total concentration of pollen grains $\left(\mathrm{x} 10^{4}\right)$ from Charland Lake. Darker 1091 zones in Sediment Type represent organic sedimentation in the piston core. Layered zones 1092 represent clay deposits. Climate Zones are derived through CONISS from Figure 3. 